\title{
JUDGMENT OF THE COURT OF JUSTICE IN C-526/14 TADEJ KOTNIK AND OTHERS V. DRŽAVNI ZBOR REPUBLIKE SLOVENIJE AND PERMISSIBILITY OF GRANTING STATE AID TO FINANCIAL INSTITUTIONS
}

\section{Eukasz Stępkowski*}

Keywords: European Union law, State aid, financial sector, financial crisis Summary: The present work explores the Court of Justice's decision in C-526/14 Tadej Kotnik and Others, along with its background, elements that led to it and subsequent developments in EU law. The author comments on the Court's reasoning to discover whether the case was decided meritoriously or per incuriam.

* Advocate, sworn [i.e. certified] translator of the English language, Ph.D. student and teaching fellow at the Faculty of Law, Administration and Economics, University of Wrocław, named partner of Konopacka i Stępkowski Law and Legal kancelaria adwokacko-radcowska (www.kslegal.eu). Research that led to writing this paper has been made possible by virtue of funding obtained from the National Science Centre (NCN), grant no. Preludium 9 - UMO-2015/17/N/HS5/02575, entitled "Sytuacja prawna przedsiębiorstwa w prawie Unii Europejskiej dotyczacym pomocy państwa”. 


\section{Introduction}

The following case commentary relates to the judgment of the Court of Justice held on 19.7.2016 in Case C-526/14 Tadej Kotnik and Others v Državni zbor Republike Slovenije, EU:C:2016:570 ${ }^{1}$ and its importance in the field of EU law on State aid. In particular, this paper explores the importance of Tadej Kotnik for a very specific and the relatively controversial area of the law on State aid, that is the temporary rules on State aid established in response to the economic and financial crisis. This commentary presents the underlying issues that led to the preliminary reference in Tadej Kotnik, the preliminary reference itself ${ }^{2}$, the subsequent Opinion of Advocate General Wahl ${ }^{3}$, the judgment at issue, and later developments in the acquis.

\section{2013 Banking Communication}

The relevant background of Tadej Kotnik is the framework of temporary rules on State aid established in response to the economic and financial crisis ${ }^{4}$. The current centrepiece of that framework, considered in the decision proper, is the Communication from the Commission on the application, from 1.8.2013, of State aid rules to support measures in favour of banks in the context of the financial crisis ${ }^{5}$, also known as the Banking Communication. The Banking Communication has been issued as a soft-law act under Article 107(3)(b) TFEU by the Commission. It adopts a 'normalising' approach to granting crisis aid in that it attempts to restrict and control grants of crisis aid. It has been therein admitted that the previous crisis rules were quite agreeable with unrestricted granting of aid (at para. 18 et seq., para. 24), especially given that is was understood

1 Hereinafter 'Tadej Kotnik'.

2 It may be noted that its text in the Court of Justice CURIA website appears to be corrupted, for no apparent reason. The reader should be advised that the preliminary reference at issue is available in PDF format at: http://eur-lex.europa.eu/legal-content/ en/TXT/PDF/?uri=uriserv\%3AOJ.C_.2015.081.01.0003.01.ENG.

3 Opinion of AG Nils Wahl, delivered on 18.2.2016, EU:C:2016:102, hereinafter 'the Opinion'.

4 See http://ec.europa.eu/competition/state_aid/legislation/temporary.html (accessible as of 28.1.2018).

5 OJ C 216, 30.7.2013, p. 1-15. 
before (pre-financial crisis, that is) that Article 107(3)(b) TFEU had had to be interpreted restrictively, a notion the Commission then largely abandoned during the crisis ${ }^{6}$. The Communication endeavours to raise the minimum requirements for creditor burden-sharing in such a way that granting any kind of restructuring aid is to be a last resort to consider, should all capital generating measures, including the conversion of junior debt, be exhausted. Thus, Member States will have to ensure, before granting restructuring aid to a bank, that shareholders and junior capital holders of that bank arranged for the required contribution or established the necessary legal framework for obtaining such contributions. However, this is subject to the caveat that fundamental rights would be respected and financial stability would not be put at risk. Additionally, the Communication reflects the idea that the greater extent of burden-sharing implies a reduced need for measures addressing competition distortions, with the proviso that such measures to limit those distortions of competition would have to be calibrated in such a way so as to approximate, as much as possible, the market situation which would have materialised if the beneficiary of the aid had exited the market without aid. Moreover, the 2013 Banking Communication refers to the avoidance or alleviation of capital shortfalls (Kapitallücke, niedobory kapitału) as its primary goal. A "capital shortfall" is to be understood as a capital shortfall established in a capital exercise, stress-test, asset quality review or an equivalent exercise at Union, euro area or national level, where applicable confirmed by the competent supervisory authority (at para. 28). If there is (or would be) an identifiable capital shortfall in regard to a credit institution ${ }^{7}$, a Member State is to draw up a capital raising plan,

6 D. Eisenhut [in:] R. Geiger, D. Khan, M. Kotzur (eds), 'EU Treaties - a Commentary', Beck Verlag, München 2015, p. 534. Cf. case Federal Republic of Germany v Commission of the European Communities, C-301/96, Judgment of the Court of 30.9.2003, EU:C:2003:509, para. 106 ("a narrow interpretation"), joined cases Freistaat Sachsen, Volkswagen AG and Volkswagen Sachsen GmbH v Commission of the European Communities, T-132/96 and T-143/96, Judgment of the Court of First Instance of 15.12.1999, EU:T:1999:326, para. 132 ("interpreted narrowly"). For the Commission's own decisions that took this thenabandoned approach, see decisions no. NN 70/2007 Northern Rock, para. 38, and no. 98/490 Credit Lyonnais, para. 10.1, wherein the Commission even stated that bail-outs of banks remained outside the scope of Article 107(3)(b) TFEU.

7 While the Communication refers to Article 4(1) of Directive 2006/48/EC as to the definition of a 'credit institution' (see footnote 10 therein), that directive has been repealed by Directive 2013/36/EU of the European Parliament and of the Council of 26.6.2013 on access to the activity of credit institutions and the prudential supervision of credit institutions and investment firms, amending Directive 2002/87/EC and 
determining the extent of capital shortfall of a bank that needs to be covered with State aid. After the identification, a Member State needs to prepare a restructuring plan in order to safeguard the compatibility of aid with the single internal market. The Communication further provides that all capital raising measures that can be implemented should be carried out. It therefore appears that Member States are invited to do whatever is necessary to avert a large shortfall, with the Communication providing a nonexhaustive list of capital-raising measures ${ }^{8}$. However, capital measures that will not have been implemented within six months from the submission of the capital raising plan are to be assessed by the Commission as to their inclusion, in consultation with the supervisory authority. Apart from capital measures, it may be required of Member States to effect burden-sharing in regard to hybrid shareholders and creditors holding subordinated debt. As it can be seen at paras 40-46, the Commission refers to the economic approach to equity and debt (incorporating risk and return from an investment), as opposed to the legal understanding of it. Furthermore, it follows that the brunt of burden-sharing is to be borne by those who hold the most risky interest in a given credit institution upwards, i.e. ordinary shareholders, followed by hybrid shareholders, to subordinated debt holders. Those interested parties would have to withstand, as to the 'contribution', either a conversion of their debt to equity or a write-down of the principal, in order to stop any cash flows to the extent legally possible. On the other hand, senior debt holders ("in particular from insured deposits, uninsured deposits, bonds and all other senior debt") are never expected to contribute. By way of an exception, the 2013 Banking Communication envisages that aid might be granted where implementing capital-raising measures would

repealing Directives 2006/48/EC and 2006/49/EC, which in turn under Article 3(1)(1) refers to Article 4(1)(1) of Regulation (EU) No. 575/2013 of the European Parliament and of the Council of 26.6.2013 on prudential requirements for credit institutions and investment firms and amending Regulation (EU) No. 648/2012. The latter defines 'credit institution' as an undertaking the business of which is to take deposits or other repayable funds from the public and to grant credits for its own account. In addition, the Communication mutatis mutandis covers insurance companies (para. 26).

8 These include (a) rights issues; (b) voluntary conversion of subordinated debt instruments into equity on the basis of a risk-related incentive; (c) liability management exercises which should in principle be $100 \%$ capital generating if the capital shortfall cannot be overcome in full and therefore State aid is required; (d) capital-generating sales of assets and portfolios; (e) securitisation of portfolios in order to generate capital from non-core activities; (f) earnings retention; ( $g$ ) other measures reducing capital needs. 
endanger financial stability or lead to disproportionate results (para. 45). The Communication echoes the 'no creditor worse off' principle at para. 46, requiring that subordinated creditors should not receive less - in economic terms - than what their instrument would have been worth if no State aid were to be granted. Against this background of "burden-sharing" expected of shareholders and certain creditors of an ailing financial institution that was introduced by the Banking Communication, a controversy has risen. Measures referred to under paragraphs 40 to 46 of the Communication have been impugned in proceedings before the Ustavno sodišče (i.e. Constitutional Court of the Republic of Slovenia), which made a preliminary reference on 9.3.2015 to the Court of Justice.

\section{Preliminary reference}

The referring court put seven questions to the Court of Justice, the first of which related to the legal nature of the Communication. For that, the referring court wished to know if the Communication was in fact binding on Member States, given its actual legal effects (granted that it further modified the approach to Article 107(3)(b) TFEU) and the Commission's role in exercising the Union's exclusive competence under Article 3(1)(b) TFEU. Secondly, the Constitutional Court also inquired about possible overreach of the Commission as to paragraphs 40-46 of the Communication and its competences under Articles 107, 108 and 109 TFEU. Should the Court of Justice answer that the Commission has not exceeded its competences, the Constitutional Court would then ask whether paragraphs $40-46$ of the Communication were, in fact, compliant with the principle of the protection of legitimate expectations and with the fundamental right to property, as enshrined in Article 17(1) of the Charter of Fundamental Rights of the European Union (CFR). Additionally, the referring court requested the Court of Justice to decide whether the condition of 'burden-sharing' in regard to the requirement to convert or write down hybrid capital and subordinated debt instruments is a condition sine qua non for the aid to be granted, or whether aid measures merely have to be proportionate. Finally, somewhat outside the breadth of State aid law, the Constitutional Court wanted to be apprised as to whether certain provisions of Directive 2012/30/EU (now, after consolidation, Directive (EU) 2017/1132 of the European Parliament and 
of the Council of 14.6.2017 relating to certain aspects of company law ${ }^{9}$ ) would affect the validity of the Banking Communication, and whether 'reorganisation measures' under Article 2, seventh indent of Directive 2001/24/EC of the European Parliament and of the Council of 4 April 2001 on the reorganisation and winding up of credit institutions, i.e. "measures which are intended to preserve or restore the financial situation of a credit institution and which could affect third parties' pre-existing rights, including measures involving the possibility of a suspension of payments, suspension of enforcement measures or reduction of claims", included 'burden-sharing' measures of the kind envisaged under paragraphs 40 to 46 of the Banking Communication. All questions have been deemed admissible by the Court.

\section{Advocate General's opinion}

Upon his review of the case at issue, AG Nils Wahl rendered his Opinion on 18.2.2016. The AG took the view that the Banking Communication, as a "soft-law" act, may never bind Member States and therefore is limited to restricting discretion of the Commission. The AG therefore concluded that the premise of the order for reference, in that the Banking Communication may at least de facto bind Member States, is incorrect ${ }^{10}$, and, as such, "any effect of those rules upon Member States can at most be incidental or indirect. Even after the publication of such a communication, Member States remain at liberty to notify the Commission of aid measures which they consider compatible, even without meeting the conditions set out in that communication". Using this finding as a point of departure, the AG found that, provided that the 2013 Banking Communication is not binding on Member States, the Commission did not exceed its competence having in mind its discretion under Article 107(3)(b) TFEU. The AG also suggested to the Court that the Communication is not capable of infringing the principle of the protection of legitimate expectations, and that it pursues the objective of ensuring the stability of the financial system while avoiding excessive public spending and minimising distortions of competition constitute overriding public interests. The latter issue,

10 Cf. paragraphs 28, 39 and 40 of the Opinion. 
in the AG's view, allows the Commission to not introduce any transition periods in the Banking Communication. Furthermore, according to the Advocate General, while the right to property might be affected by burden-sharing measures, the Banking Communication constitutes neither a permission to expropriate nor a licence to infringe any fundamental rights, in particular because the Communication refers to principles of market approximation and 'no creditor worse off ${ }^{11}$. There is, according to the AG, a distinction between the Communication itself, and aid measures undertaken by a Member State on its basis; the latter would have to be scrutinised by national courts. The AG emphasised the fact that there is no right to receive aid under EU law because it is the policy choice of Member States; Member States have other means at their disposal than granting aid - where they do grant aid, the Commission is to review it, but not to substitute itself for Member States ${ }^{12}$. Additionally, the AG found no issue as to Directives 2012/30/EU and 2001/24/EC. Finally, the analysis of AG Wahl has led to a finding that - as regards to parties that hold rights flowing from hybrid capital and subordinated debt instruments - conversion or writing-down of hybrid capital and subordinated debt instruments is not a sine qua non requirement for the grant of aid under the Banking Communication, and it is "not required when it would lead to disproportionate results ${ }^{13}$ ". In sum, the AG essentially invited the Court to decide that the Banking Communication is not binding on Member States and that it is in line with existing EU law. It is indeed true that a genuine soft-law act may not normally, in and of itself, bind Member States; its principal legal effects amount to an aid in interpretation, in particular where it casts light on the interpretation of national measures adopted in order to implement EU law or where it is designed to supplement binding provisions of EU law ${ }^{14}$. It may not be interpreted in a manner contrary to the binding EU law it supplements ${ }^{15}$. It is also true that, in the field of State aid, the Commission's discretion is limited by a soft-

11 Cf. paragraphs 68, 69, 76 and 92 therein.

12 Cf. para. 82.

13 Cf. para. 130 therein.

14 See, among other authorities, case Salvatore Grimaldi $v$ Fonds des maladies professionnelles, C-322/88, Judgment of the Court of 13.12.1989, EU:C:1989:646, para. 18, case Altair Chimica SpA v ENEL Distribuzione SpA, C-207/01, Judgment of the Court of 11.9.2003, EU:C:2003:451, para. 41.

15 Cf. case 'Baltlanta' UAB v Lietuvos valstybè, C-410/13, Judgment of the Court of 3.9.2014, EU:C:2014:2134, para. 65. 
law act it issues and that the Commission is bound thereby the extent that such rules do not depart from the rules in the TFEU, including, in particular, Article 107(3)(b) TFEU, and to the extent that their application is not in breach of general principles of law, such as equal treatment, in particular where exceptional circumstances, other than those envisaged in those guidelines, distinguish a given sector of the economy of a Member State ${ }^{16}$. However, the AG failed to admit that, at least in the field of State aid, there can be soft-law rules that are genuinely binding on Member States, to the extent where Member States agree to their introduction ${ }^{17}$. This "type" of soft-law is primarily known to occur in the field of State aid and for the purposes of periodic review under Article 108(1) TFEU ${ }^{18}$. In addition, its binding legal effects in regard to Member States themselves are settled case-law, well-known before the AG gave his Opinion ${ }^{19}$. In the case of the Banking Communication, it may be conceded that it is not expressly based on Article 108(1) TFEU, but, formally speaking, solely on Article 107(3)(b) TFEU. Nevertheless, the Communication was indeed adopted as a response to the changing situation on the market over which the Commission keeps its review. It is also apparent from the discussion in Tadej Kotnik on the order of reference that the Member State at issue

16 Cf. case Hellenic Republic v European Commission, C-431/14 P, Judgment of the Court of 8.3.2016, EU:C:2016:145, para. 70, case Holland Malt BV v European Commission, C-464/09 P, Judgment of the Court of 2.12.2010, EU:C:2010:733, para. 47.

17 Cf. case IJssel-Vliet Combinatie BV v Minister van Economische Zaken, C-311/94, Judgment of the Court of 15.10.1996, EU:C:1996:383, para. 44, O. Ştefan, Soft Law in Court, Wolters Kluwer, Alphen aan den Rijn 2013, p. 176.

18 The so-called "negotiated State aid soft-law", see O. Ştefan, op. cit., pp. 181 and 189.

19 See case Ladbroke Racing Ltd $v$ Commission of the European Communities, T-67/94, Judgment of the Court of First Instance of 27.1.1998, EU:T:1998:7, para. 189, case Federal Republic of Germany $v$ Commission of the European Communities, C-288/96, Judgment of the Court of 5.10.2000, EU:C:2000:537, para. 64; see also a set of Judgments of the Court of 4.12.2013, cases European Commission v Council of the European Union, C-111/10 (EU:C:2013:785), C-117/10 (EU:C:2013:786), C-118/10 (EU:C:2013:787), and C-121/10 (EU:C:2013:784), wherein the Court stated that "When [soft-law rules] are based on Article 108(1) TFEU, those [rules] constitute one element of the regular and periodic cooperation under which the Commission, in conjunction with the Member States, must keep under constant review existing systems of aid and propose to them any appropriate measures required by the progressive development or by the functioning of the common market (...). To the extent that those proposals for appropriate measures are accepted by a Member State, they are binding upon that State (...) which must, as Article 19(1) of Regulation No. 659/1999 states, implement them (e.g. para. 51 in C-111/10)". 
transposed the Banking Communication into its national law, which led the referring Court to issue that order (and national claimants to bring constitutional complaints in the first place $)^{20}$. In addition, there already are some dicta under what is now Article 107(3) TFEU to the effect that it is the Commission primarily, but not exclusively, who is bound by guidelines it issues ${ }^{21}$, where Member States accept such guidelines ${ }^{22}$. Therefore, it can be at least argued that the Member State at issue accepted this particular soft-law act into its legal system by way of transposition. By virtue of that, the Banking Communication could have been capable of having certain binding effects vis-à-vis that Member State either under CIRFS and IJsselVliet case-law, under a possible elaboration of what the Court implied in para. 69 of C-409/00 Spain/Commission, or possibly all of them at once, a possibility the AG did not explore. Instead, the AG opted for a formalistic approach, merely stating that the Communication is incapable of being binding, even de facto, either on Slovenia or on Member States in general, by virtue of being a soft-law act. The AG did so without scrutinising either the general effect of accepting guidelines into national law, or the actual effect of that particular transposition in the case at issue. The AG also failed to address the possibility of the Banking Communication to be an irregular act that is actually aimed at producing legal effects, despite

20 Cf. Tadej Kotnik, para. 29: "It is stated in the order for reference that the objective of the provisions of the law on the banking sector was to transpose the Banking Communication into national law, in order to enable the national authorities to grant to undertakings in that sector State aid that was compatible with the internal market. Consequently, according to the referring court, while the objections of the applicants in the main proceedings are directed against those provisions, their actual target is the Banking Communication".

21 Compare case Kingdom of Spain v Commission of the European Communities, C-409/00, Judgment of the Court of 13.2.2003, EU:C:2003:92, para. 69: “(..) those notices and guidelines apply primarily [emphasis added] to the Commission itself". See also the 'acceptance' of Member States noted by the Court as a requirement for a binding nature of a guideline, joined cases Federal Republic of Germany (C-75/05 P), Glunz AG and OSB Deutschland GmbH (C-80/05 P) v Kronofrance SA, Judgment of the Court of 11.9.2008, EU:C:2008:482, para. 61, case Italian Republic v Commission of the European Communities, C-91/01, Judgment of the Court of 29.4.2004, EU:C:2004:244, para. 45.

22 See also case Comité International de la Rayonne et des Fibres Synthétiques and others $v$ Commission of the European Communities (CIRFS), C-313/90, Judgment of the Court of 24.3.1993, EU:C:1993:111, para. 33-36, on a binding guideline adopted by the Commission and accepted by Member States, where what is now Article 108(3) TFEU, and not Article 108(1) TFEU, applied. 
allegedly being soft-law. It is common knowledge that it is not the name of the act, but its contents that determine its nature ${ }^{23}$. It was not in dispute that 'burden-sharing' measures, in this form, are a novel feature under Article 107(3)(b) TFEU despite the fact that the notion of a contribution of an aid beneficiary might not be new ${ }^{24}$. Requiring non-beneficiaries to contribute in order to improve the situation of a beneficiary might be a rather novel interpretation of Article 107(1) TFEU taken together with Article 107(3)(b) TFEU, all the more where the Commission has no binding power to authoritatively interpret the notion of State aid $^{25}$ and has no selfstanding legislative powers.

\section{Judgment in Tadej Kotnik}

On 19.7.2016, the Court, sitting as a Grand Chamber composed of K. Lenaerts, President, A. Tizzano, Vice-President, along with R. Silva d Lapuerta, T. von Danwitz, J.L. da Cruz Vilaça (who served as a Rapporteur), A. Arabadjiev, C. Toader and D. Šváby, Presidents of Chambers, with M. Safjan, M. Berger, E. Jarašiūnas, C.G. Fernlund and C. Vajda, who were sitting as Judges, decided the case at issue. The Court noted at the outset that the substance of the case concerns a condition that there must be burden-sharing by shareholders and subordinated creditors for

23 See K. Lenaerts, I. Maselis, K. Gutman, EU Procedural Law, Oxford University Press, Oxford 2015, p. 464.

${ }^{24}$ Cf. para. 55 of the Opinion. It is telling that the AG refers to case-law on firms in difficulty; while it is not controversial that a recipient of restructuring aid (the aid beneficiary) should make a genuine contribution to the firm in difficulty, 'burdensharing' measures do not refer to an aid beneficiary (the financial institution), but to shareholders and subordinated creditors. While shareholders may sometimes be considered a component of the undertaking that is an aid beneficiary (where they involve themselves in management of the entity that receives aid, cf. case Ministero dell'Economia e delle Finanze v Cassa di Risparmio di Firenze SpA, Fondazione Cassa di Risparmio di San Miniato and Cassa di Risparmio di San Miniato SpA, C-222/04, Judgment of the Court of 10.2.2006, EU:C:2006:8, para. 111 and 112, para. 16 of the Commission Notice on the notion of State aid as referred to in Article 107(1) of the Treaty on the Functioning of the European Union, OJ 2016/C 262/01), deeming creditors a part thereof under EU State aid law seems rather far-fetched.

25 See case Administración del Estado v Xunta de Galicia, C-71/04, Judgment of the Court of 21.7.2005, EU:C:2005:493, para. 37. 
the Commission to deem aid compatible with the internal market on the basis of Article 107(3)(b) TFEU ${ }^{26}$. It should be noted that the Court did say that condition was laid down by the Commission (and hence, not expressly provided for under Article 107(3)(b) TFEU). Having said that, the Court moved on to the referred questions. It confirmed that in the exercise of its "wide discretion, the exercise of which involves complex economic and social assessments" under Article 107(3) TFEU, the Commission may adopt guidelines in order to establish the criteria on the basis of which it proposes to assess the compatibility, with the internal market, of aid measures envisaged by the Member States. According to the Court, in adopting such guidelines and announcing by publishing them that they will apply to the cases to which they relate, the Commission imposes a limit on the exercise of that discretion and cannot, as a general rule, depart from those guidelines, at the risk of being found to be in breach of general principles of law, such as equal treatment or the protection of legitimate expectations ${ }^{27}$. On the other hand, the Court stressed that the Commission may not waive the exercise of its discretion; The adoption of a communication such as the Banking Communication does not, according to the Court, relieve the Commission of its obligation to examine the specific exceptional circumstances relied on by a Member State, in a particular case, for the purpose of requesting the direct application of Article 107(3)(b) TFEU, and to provide reasons for its refusal to grant such a request ${ }^{28}$. Applying those principles to the case at issue, the Court held that, on the one hand, the effect of the Banking Communication shows itself in limiting discretion of the Commission; in principle, where its requirements are satisfied, the Commission may not refuse, "as a general rule", to authorize proposed State aid. On the other, Member States remain free to apply for authorization under Article 107(3)(b) TFEU, applied on its own, "and the Commission may authorize such proposed aid in exceptional

26 Para. 33 of the Judgment: “(...) this case concerns the compatibility, with a number of provisions of EU law, of the condition laid down by the Commission [emphasis added] that there must be burden-sharing by shareholders and subordinated creditors, if it is to be able to find, under Article 107(3)(b) TFEU, that the State aid granted in the banking sector is compatible with the internal market. The validity of such a condition must be capable of being reviewed by the Court in the procedure provided for by Article 267 TFEU, and that is precisely the subject-matter of the second, third, fourth and fifth questions referred".

27 Para. 38, 39 and 40 of the Judgment.

28 Para. 41 of the Judgment. 
circumstances". The Court further added that "the Banking Communication is not capable of imposing independent obligations on the Member States, but does no more than establish conditions, designed to ensure that State aid granted to the banks in the context of the financial crisis is compatible with the internal market, which the Commission must take into account in the exercise of the wide discretion that it enjoys under Article 107(3) (b) TFEU", holding in sum that the Communication is not binding on the Member States ${ }^{29}$. However, this reasoning implicitly confirms that the Communication is capable of imposing obligations that are dependent on some other source(s) of EU law, given that the Court did not say that it is, simply put, incapable of imposing obligations in general. This approach resembles the one taken in regard to directives being 'made effective' by general principles of law of the Union (and vice versa), as seen e.g. in Mangold ${ }^{30}$. In addition, the Court affirmed that, where the Communication would not apply, Article 107(3)(b) TFEU could serve as a direct basis for the authorization of aid only exceptionally. As the latter position was the norm in pre-crisis times (as in, e.g. C-301/96 Germany/Commission above), the Court's approach to Article 107(3)(b) TFEU appears to "normalise" the state of affairs. Conversely, as the Communication is meant to apply outside such exceptional situations that relate to a risk of financial stability or a threat to the principle of proportionality (viz. para. 45 thereunder), it may be seen as setting a lower standard for the authorization of aid $^{31}$ than Article 107(3)(b) TFEU taken alone. The Court did not pursue the possibility of either exploring its own dicta in C-409/00 Spain/Commission, CIFRS or IJssel-Vliet or giving guidance on the issue of 'acceptance' on the part of Member States.

Further on, as to the second question referred by the Constitutional Court on compatibility of paragraphs $40-46$ of the Communication with Articles 107-109 TFEU, the Court recalled its earlier finding in HGA, in that

30 That is, case Werner Mangold v Rüdiger Helm, C-144/04, Judgment of the Court of 22.11.2005, EU:C:2005:709, para. 76. For a more recent case, see case Dansk Industri (DI), acting on behalf of Ajos A/S v Estate of Karsten Eigil Rasmussen, C-441/14, Judgment of the Court of 19.4.2016, EU:C:2016:278, para. 35.

31 Further still, that standard would still be stricter than the one employed by the Commission during the financial crisis (as in, effectively nil), where Article 107(3) (b) TFEU was used to approve some 4000 billion EUR from October 2008 to March 2010 through aid schemes alone (A. Rosenfeld [in:] F. Säcker, F. Montag (eds), 'European State Aid Law', Beck Verlag, München 2016, p. 1291). 
aid which improves the financial situation of the recipient undertaking but is not necessary for the attainment of the objectives specified in Article 107(3) TFEU cannot be considered to be compatible with the internal market ${ }^{32}$. Building on that, the Court arrived at a conclusion that the Communication complies with Articles 107-109 TFEU, and that the Commission was entitled to consider that "burden-sharing measures were essential in order that State aid in the banking sector should be limited to the minimum necessary and that any distortions of competition in the internal market should be limited ${ }^{33 "}$. That conclusion is justified, according to the Court, by the need to 'prevent recourse to State aid as a tool to overcome financial difficulties of the banks concerned', the likelihood of such measures to limit the amount of State aid granted, and the need to counteract moral hazard ${ }^{34}$. An interesting feature of the Court's decision is found under paragraph 57 therein; the Court stated that

to act otherwise [i.e. not require burden-sharing] would be liable to cause distortions of competition, since banks whose shareholders and subordinated creditors had not contributed to the reduction of the capital shortfall would receive State aid of an amount greater than that which would have been sufficient to overcome the residual capital shortfall. In those circumstances, such aid would not, as a general rule, be compatible with EU law [emphasis added].

In the author's view, paragraph 57 of the case at issue constitutes a further obstacle to permitting aid directly under Article 107(3)(b) TFEU, as it undermines the Court's own statement under para. 43 that Member States "retain the right" to notify aid not compliant with the Banking Communication. If such an aid is to be, as a general rule, not compatible with EU law, then the "right" to notify such aid is, as a general rule, rendered meaningless, at least outside a wanton need to receive a negative Article 108(3) TFEU decision on proposed aid from the Commission. The Court of Justice has also shared the view of the Advocate-General on the issue of legitimate expectations and the right to property. First, it found no issue with the protection of legitimate expectations, as the sole fact that

32 See para. 49 of joined cases HGA Srl and Others (C-630/11 P), Regione autonoma della Sardegna (C-631/11 P), Timsas srl (C-632/11 P) and Grand Hotel Abi d'Oru SpA (C-633/11 P) $v$ European Commission, Judgment of the Court of 13.6.2013, EU:C:2013:387, para. 104.

33 Para. 54 of the Judgment.

34 See para. 55, 56 and 58 of the Judgment. It might be added that this reasoning is quite cursory. 
shareholders and subordinated creditors were not required to participate in bearing the brunt of the financial crisis at first does not constitute precise, unconditional and consistent assurances, originating from authorised, reliable sources. Even if there were such assurances, they could not justify, according to the Court, any transitional period for the Communication, due to the fact that "an overriding public interest may preclude transitional measures from being adopted in respect of situations which arose before the new rules came into force but which are still subject to change ${ }^{35}$ ". For the AG and the Court, the objective of ensuring the stability of the financial system while avoiding excessive public spending and minimising distortions of competition constitutes an overriding public interest of that kind. As to the right to property, the Court has, in essence, confirmed the AG's view that the right to property is not infringed by the Banking Communication. However, the Court made no express distinction between the Banking Communication itself and aid measures that involve burden-sharing. Where the AG admitted that burden-sharing measures are capable of severely affecting shareholders' and creditors' rights to property "if adopted against the will of the shareholders and creditors of banks to be recapitalised", and surmised that national courts would have to check those measures in casu, the Court of Justice flatly stated that it "cannot reasonably be maintained that the burden-sharing measures, such as those laid down by the Banking Communication, constitute interference in the right to property of the shareholders and the subordinated creditors". The reason for that, according to the Court, is that write-down or write-off of value merely adjusts the shares or the debt at issue to their economic value ${ }^{36}$. This approach ignores the possible severity of involuntary burden-sharing

35 Para. 68 of the Judgment; on that, the Court shared the AG's citation of case Affish BVv Rijksdienst voor de keuring van Vee en Vlees, C-183/95, Judgment of the Court of 17.7.1997, EU:C:1997:373, para. 57. See also case Commission of the European Communities v Koninklijke FrieslandCampina NV, C-519/07 P, Judgment of the Court of 17.11.2009, EU:C:2009:556, para. 85 .

36 Cf. paragraphs 75 and 79 of the Judgment. The Court did say that, in the case of subordinated creditors, their contribution is a last resort (“(...) those creditors are to contribute to reducing the capital shortfall (i) only after losses are first absorbed by equity and (ii) only 'if there are no other possibilities' available to overcome any capital shortfall in the bank concerned or where that bank no longer meets the minimum regulatory capital requirements") and that the 'no creditor worse off' principle should be complied with. However, "no less in economic terms" than what the creditors could have received in insolvency proceedings is always an exercise in probability; in addition, where such an exercise is mandatory, it extinguishes any possibility of trading the right 
and the fact that a possibility of mandatory measure may limit the value of their shares or claims. The Court's reasoning is therefore less nuanced that that of the AG. Further on, the Court considered the issues related to the fifth question on Directive 2012/30/EU, the sixth question on proportionality and the seventh question on Directive 2001/24/EC and its reorganisation measures. The Court largely followed the AG on all those matters. As to the fifth question, the Court confirmed that its judgment in Pafitis ${ }^{37}$ is not relevant to the facts of the case and may not be read as precluding burden-sharing measures where they would be decided without the approval of the company general meeting; neither is Directive 2012/30/ EU, held to not constitute an obstacle to the Banking Communication ${ }^{38}$. The sixth question grappled with burden-sharing measures in regard to the writing down of subordinated rights, the issue being whether those rights must always be written down in accordance with paragraph 44 of the Banking Communication ${ }^{39}$. The Court confirmed that compliance with paragraph 44 is sufficient for aid to be approved, but disagreed on its mandatory character, stating that a Member State may choose not to require a write-down of subordinated rights, but in doing so, risks any aid granted in such a manner being deemed incompatible with the internal market. The Court of Justice added that no write-down of such rights is required where this would be disproportionate, i.e. not necessary to overcome the capital shortfall of the bank concerned ${ }^{40}$. The seventh and last question was also swiftly dealt with, with the Court stating that 'burden-sharing' measures do constitute reorganisation measures within the meaning of Directive 2001/24/EC, where they are not voluntary ${ }^{41}$. However, in so doing, the Court of Justice contradicted itself - it did admit that

at issue (e.g. through factoring), leaving those affected with more limited options, and hence, worse off.

37 That is, case Panagis Pafitis and others v Trapeza Kentrikis Ellados A.E. and others, C-441/93, Judgment of the Court of 12.3.1996, EU:C:1996:92.

38 Para. 89 and 94 of the Judgment.

39 A literal reading of that paragraph would suggest so: "In cases where the bank no longer meets the minimum regulatory capital requirements, subordinated debt must be converted or written down [emphasis added], in principle before State aid is granted. State aid must not be granted before equity, hybrid capital and subordinated debt have fully contributed to offset any losses".

40 Para. 102 of the Judgment.

41 Para. 110 of the Judgment. 
the burden-sharing measures, in particular the conversion of the principal of subordinated rights into equity or the write-down of the principal, are, by their very nature, likely adversely to affect the pre-existing rights of third parties and, accordingly, to lead to a reduction of creditors' claims ${ }^{42}$

It is not readily apparent why the Court would not admit that where it scrutinised, for instance, the right to property, but could do so elsewhere in the same decision ${ }^{43}$. In sum, the Court found that the Communication is not binding, that it neither infringes Articles 107-109 TFEU nor does it breach the principle of the protection of legitimate expectations and the right to property, that burden-sharing measures in regard to subordinated debt are not mandatory but their absence creates a risk for Member States under Article 107(3)(b) TFEU (and they must be proportional), and that Directives referred to in the order are legally irrelevant for validity of the Banking Communication.

\section{Later developments in the acquis and conclusions}

The decision in Tadej Kotnik was subsequently referred to by the Court in Dowling, on the point that extraordinary reorganisation measures in regard to a public limited liability company need not be approved by the general meeting ${ }^{44}$. Tadej Kotnik was also recalled on occasion by the General Court ${ }^{45}$. More generally, absence of measures of the kind envisaged in Tadej Kotnik was noted in Commission Decision (EU) $2016 / 1208$ of 23.12 .2015 on State aid granted by Italy to the bank

42 Para. 109 therein.

43 Apart from a plausible need to arrive at a pre-set solution, that is. It was not clear for the AG why the referring court would specifically ask this last question (para. 132 of the Opinion), but the Court did not press the issue.

44 Case Gerard Dowling and Others $v$ Minister for Finance, C-41/15, Judgment of the Court of 8.11.2016, EU:C:2016:836, para. 51.

45 Case Regione autonoma della Sardegna v European Commission, T-219/14, Judgment of the General Court of 6.4.2017, EU:T:2017:266, para. 177, as to the Commission being unable to waive the exercise of its discretion when assessing compatibility of State aid; case Bayerische Motoren Werke AG v European Commission, T-671/14, Judgment of the General Court of 12.9.2017, EU:T:2017:599, para. 145, as to the principle of proportionality 'consisting in limiting aid to the minimum necessary so as to reduce distortions in the internal market' is relevant in various areas of State aid law. 
Tercas, where inter alia lack of burden-sharing on the part of subordinated debt holders was indicated for prompting recovery of aid $^{46}$. To conclude, it may be said that Tadej Kotnik's importance lies in affirming the validity of the 2013 Banking Communication ${ }^{47}$, notwithstanding several issues with the decision itself. Tadej Kotnik, along with the Communication, serve as a stepping stone towards "normalising" Article 107(3)(b) TFEU. For now, however, the Commission is left with a considerable degree of norm-generating authority under Article 107(3)(b) TFEU, and the levels of stringency envisaged in e.g. C-301/96 Germany/Commission have not returned.

\section{Bibliography}

1. Bacon K. (ed.), European Union State Aid Law, Oxford University Press, Oxford 2017

2. Geiger R., Khan D., Kotzur M. (eds), EU Treaties - A Commentary, Beck Verlag, München 2015

3. Lenaerts K., Maselis I., Gutman K., EU Procedural Law, Oxford University Press, Oxford 2015

4. Säcker F., Montag F. (eds), European State Aid Law, Beck Verlag, München 2016

5. Ştefan O., Soft Law in Court, Wolters Kluwer, Alphen aan den Rijn 2013

46 OJ L 203, 28.7.2016, p. 1-34, para. 226.

47 See D. Piccinin [in:] K. Bacon (ed.), 'European Union State Aid Law', Oxford University Press, Oxford 2017, p. 570. 